\title{
Mioma gigante calcificado en paciente con TM vesical
}

\author{
D. Pascual Regueiro, E. Mallén Mateo, P. Serrano Frago, M. Blas Marín, LA Rioja Sanz \\ Servicio de Urología. Hospital Universitario Miguel Servet. Zaragoza
}

Actas Urol Esp 2005; 29 (5): 530

$\mathrm{P}^{\mathrm{a}}$ aciente de 67 años de edad que es atendida en urgencias por presentar cuadro de molestias hipogástricas y hematuria fluida. El cuadro había sido etiquetado de infección urinaria y tratado con antibiótico durante un periodo de dos semanas. Al ingreso se evidencia una hematuria macroscópica fluida y dolor a la exploración abdominal notándose masa dura en hipogastrio. El tacto vaginal revela la existencia de una tumoración de consistencia pétrea con la duda, dada la clínica, de tumor urológico o ginecológico de carácter infiltrante. En el estudio se realiza radiografía simple de abdomen que pone de manifiesto la naturaleza de la masa, tratándose de un mioma uterino gigante calcificado. Dada la hematuria, se decide llevar a cabo una revisión endoscópica vesical con el hallazgo de una tumoración papilar en fondosuelo vesical de aspecto superficial, realizándose una resección completa de la misma. El resultado anatomopatológico fue de carcinoma transicional pT1 G2. Dada la persistencia de las molestias abdominales, la paciente al alta fue remitida a consultas de ginecología para la valoración de tratamiento del mioma uterino.

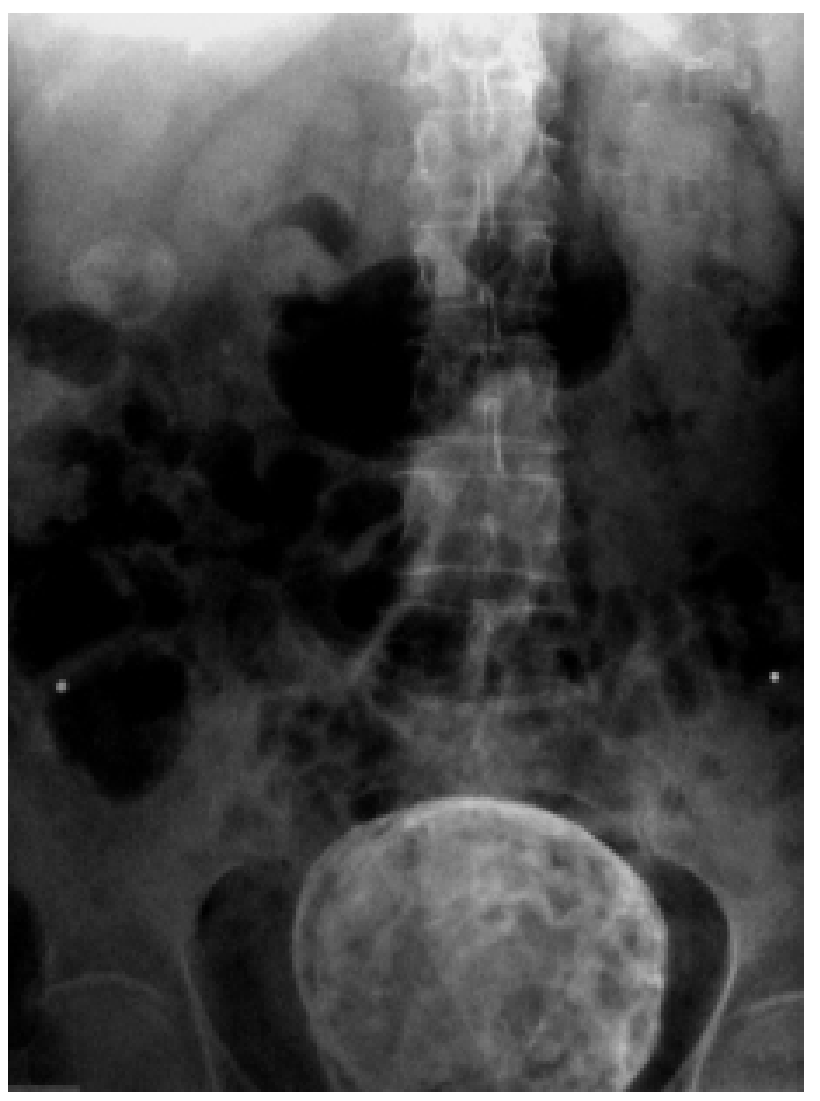

